\title{
ADSORPTION AND CHARACTERIZATION OF Pb(II) ION ONTO POROGEN ADSORBENT MEMBRANE (CC-Pec-BADGE- Na): KINETIC, EQUILIBRIUM AND THERMODYNAMIC STUDIES
}

\author{
B. Hastuti ${ }^{*}$, D. Siswanta ${ }^{2}$, Mudasir ${ }^{2}$ and Triyono ${ }^{2}$ \\ ${ }^{1}$ Department of Chemistry Education, Faculty of Faculty of Teacher Training and \\ Education,Universitas Sebelas Maret, J1. Ir. Sutami 36A Surakarta, Indonesia \\ ${ }^{2}$ Department of Chemistry, Faculty of Mathematics and Natural Sciences, \\ Universitas Gadjah Mada, Sekip Utara, Yogyakarta, Indonesia \\ *E-mail : Budihastuti@staff.uns.ac.id
}

\begin{abstract}
Adsorbent such as pectin (Pec) and chitosan (Chi) usually produced with low physical stability, thus the material needs to be modified. In this research, the physical characteristic of adsorbent increased by grafted Chi using acetate carboxymetyl chitosan (CC). Further, $\mathrm{CC}$ and Pectin (Pec) were cross-linked using cross-linked agent bisphenol A diglycidyl ether (BADGE) to get CC-Pec-BADGE(CPB) adsorbent. The cross-linked processing was targeted to formed stable structure and resistance on acidic media. Furthermore, to increase the adsorption capacity in removing $\mathrm{Pb}(\mathrm{II})$, the adsorbent was added with $\mathrm{NaCl}$ particle to form a macroporous adsorbent named CC-Pec-BADGE$\mathrm{Na}(\mathrm{CPB}-\mathrm{Na})$. The physical and chemical characterization of the photogenic adsorbent structure were characterized by scanning electron microscopy (SEM) and Fourier transform infrared spectroscopy (FT-IR). The parameter adsorption of $\mathrm{CPB}-\mathrm{Na}$ to adsorb $\mathrm{Pb}$ (II) ion was determined. The kinetics and thermodynamic of the bath sorption of $\mathrm{Pb}$ (II) on CPB-Na adsorbent and using Chi and Pec as a comparison have been investigated. The result of this study showed that the CPB-Na biosorbent stable on acidic media, had a rough and porous surface area, increasing sorption capacity and give the higher capacity for removing of $\mathrm{Pb}$ (II) ion. The CPB-Na $1 / 1$ and $1 / 3$ adsorbent adsorb $\mathrm{Pb}$ (II) with adsorption capacity $45.48 \mathrm{mg} / \mathrm{g}$ and $45.97 \mathrm{mg} / \mathrm{g}$ respectively, whereas Pec and Chi was $39.20 \mathrm{mg} / \mathrm{g}$ and $24.67 \mathrm{mg} / \mathrm{g}$ respectively.
\end{abstract}

Keywords: Porogen, $\mathrm{Pb}(\mathrm{II})$, Pectin, Carboxymethyl Chitosan(CC), CC-Pec-BADGA-Na

C RASĀYAN. All rights reserved

\section{INTRODUCTION}

Aquatic wastes containing $\mathrm{Pb}$ ionic pollutants that exceed the threshold are extremely harmful to human health. $\mathrm{Pb}$ ion in the blood can not be excreted through the excretory system, but it will accumulate in the blood. $\mathrm{Pb}$ ion can cause damage to the central nervous system. It can also damage the kidneys, liver and reproductive system, basic cellular processes and brain function. Symptoms of poisoning are characterized by anemia, insomnia, headache, dizziness, irritability, muscle weakness, hallucinations and kidney damage. ${ }^{1,2}$ Its levels in the environment are increasing due to mining, smelting and its various uses in the industry. Lead with a dark gray powder forming is used as the raw material of batteries and ammunition, paint making components, tetraethyl lead plants, radiation shields, pipe layers, cable wrappers, ceramic glass, electronic goods, tubes or containers, also in Brazing processes.

Many commonly used waste treatment technologies and its development are ion exchange, reverse osmosis, oxidation-reduction, solvent extraction, cementation, plant leaf extraction, electrochemical treatment technologies and membrane separation filtration, precipitation, and adsorption. ${ }^{1,3-8}$ The adsorption method becomes an option because it is very efficient, easy, cheap and environmentally friendly. ${ }^{9-11}$ Adsorption is the absorption of a substance (molecule or ion) on the surface of the adsorbent. The mechanism of application can be distinguished into physical sorption and chemical sorption. In the physisorption process,

Rasayan J. Chem., 13(4), 2325-2331(2020)

http://dx.doi.org/10.31788/ RJC.2020.1344091

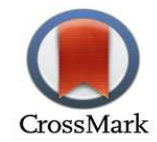


RASĀYAN J. Chem.

Vol. 13 | No. 4 |2325-2331| October - December | 2020

adsorbates bonded by the adsorbents held by van der Waals forces. ${ }^{12}$ The bonded molecule is very weak and the energy released at relatively low physical adsorption is less than $20 \mathrm{~kJ} / \mathrm{mol}^{13}$ Pectin an anionic polysaccharide is usually present in plant cell walls, based on a-(1-4) linked D-galacturonic acid. ${ }^{14} \mathrm{Pec}$ has many active groups. The hydroxyl, carboxyl, amide and methoxy are the main functional groups contained in the Pec. ${ }^{15}$ Today Pec is widely applied in various fields for daily humans such as in the food industry, as an adsorbent to remove heavy metal ion, used in pharmaceuticals field, cosmetics and medical field. ${ }^{16,17}$ Pec contains a lot of active groups, that can be used as a source biosorbent. ${ }^{15}$ The hydroxyl, carboxyl, amide and methoxyl are the main functional groups of Pec. It can be used to bind heavy metals, especially hydroxyl groups. ${ }^{18}$

Biomaterials afford to be acting as biosorbent aside from Pec is Chi. This biopolymer can adsorb heavy metals pollutants in the water because of its amine $\left(-\mathrm{NH}_{2}\right)$ and hydroxyl $(-\mathrm{OH})$ groups, which is highly reactive and alkaline. However, Chi is easily soluble in acetic acid, it also partially soluble in dilute acids, such as $\mathrm{HNO}_{3}, \mathrm{HCl}, \mathrm{HClO}_{4}$, and others, so that the direct use of Chi as an adsorbent will be less effective. In acidic conditions, the number of amine groups which is an active group that capable to bind metal ions will be reduced. So to solve this problem, Chi chains must be crosslinked to improve the stability and hold up with the acid condition. Several Chi cross-linker agents are suitable for chitosan such as Glutaraldehyde, epichlorohydrin chloromethyl oxirane, polyethylene glycol (PEG), ethylene diamine diglycidyl ether (EDGE) and so on. Cross-linked chitosan is an insoluble acids condition because it is very stable. ${ }^{19}$

\section{EXPERIMENTAL}

\section{Material}

Chitosan (Chi) was obtained from IPB (Bogor Agricultural Institute), West Java Indonesia, Pectin (Pec) produced from apple peel, was obtain from UD Organik, from the agricultural area in Sleman District, Special Region of Yogyakarta, Bisphenol A Diglycidyl Ether (BADGE) were purchased from SigmaAldrich (Germany), chloroacetic acid, acetone, $\mathrm{NaOH}$, ethanol, and metals standard solution of $\mathrm{Pb}(\mathrm{II})$ were purchased from E. Merck (Germany).

\section{Synthesis of Macroporous Adsorbent CPB-Na}

$\mathrm{CC}$ and pectin were dissolved in $2.5 \%$ acetic acid respectively then mixed and added by BADGE crosslinker agent. $\mathrm{NaCl}$ is particle pore maker then added into the adsorbent with a ratio of adsorbent and $\mathrm{Na}$ is $=1: 1$, 2: 1 and 3: 1. Furthermore, all of the solutions stirred for 3 hours and then allowed for 24 hours, molded into the weighing glass and dried. Once dried, removed from the weighing glass by dripping of $0.05 \mathrm{M}$ $\mathrm{NaOH} 25 \mathrm{ml}$ then washed it with distilled water and then dried a gel.

\section{Procedure Interaction of $\mathrm{Pb}$ (II) Ion on the CPB-Na Porogen Adsorbent}

The adsorbent adsorption capacity of metal ions is determined by adding $10 \mathrm{mg}$ of adsorbent to $10 \mathrm{~mL}$ of $50 \mathrm{mg} / \mathrm{L} \mathrm{Pb}$ ion with a variation of $\mathrm{pH}$, contact time, and adsorbed $\mathrm{Pb}$ (II) concentration. For each variation, the filtered solution and $\mathrm{Pb}$ concentration were measured by atomic absorption spectrophotometry (Hitachi 170-30 atomic absorption spectrophotometer).

\section{RESULTS AND DISCUSSION}

In this study material used for the absorbent derivate from the material of pectin and chitosan, because it can be used as a biomaterial that can absorb the metal. Pectin with carboxylic active groups and chitosan with the amine groups. They are very reactive material, can bind a metal by forming a complex compound. Pectin combined with chitosan to forms stable polyelectrolyte complexes ${ }^{17}{ }^{7}$ The interaction between COOof pectin active group and $-\mathrm{NH}_{2}$ of chitosan active group reinforce the character of these macromolecules. Its complexes usually have an organized structure that is very different from its original properties.

\section{Characterization of the Active Group using FTIR Spectra}

In this research, synthetic of the porogen adsorbent CPB-Na products yellowish-white powder form which is characterized by Fourier Transform Infra-Red Spectroscopy (FTIR) and Scanning electron microscope (SEM) with a show in Fig.-1 and Fig.-2.

Figure-1 shows that the FTIR absorption of CC appears at wavenumber $3448 \mathrm{~cm}^{-1}$ which indicates to stretching vibration of $-\mathrm{OH}$ groups overlapping with $-\mathrm{NH}$ stretching vibration. The stretching vibration of 
RASĀYAN J. Chem.

Vol. 13 | No. 4 |2325-2331| October - December | 2020

$\mathrm{CH}$ on wave number $2962 \mathrm{~cm}^{-1}$ for $\mathrm{CPB}^{18}$, shifted from to peak at $2924 \mathrm{~cm}^{-1}$ for CPB-Na $1 / 1$ and peak at $2916 \mathrm{~cm}^{-1}$ for CPB-Na 1/3. The CC characteristic peak appears at 1604 and $1450 \mathrm{~cm}^{-1}$ which indicates the presence of the carboxylic group (-COOH), and shifted to 1620 and $1458 \mathrm{~cm}^{-1}$ wave number for CPB-Na $1 / 3$. Absorption at $1628 \mathrm{~cm}^{-1}$ is the absorption of $-\mathrm{COOH}$ group.

The FTIR spectra of Chi at 3464 and $3433 \mathrm{~cm}^{-1}$ indicated the vibration of the hydroxyl group groups overlapping with $-\mathrm{NH}$ stretching vibration. Figure-1 showed the FTIR spectra of synthesized porogen adsorbent CPB-Na (b) and (c) compared to the CPB adsorbent (a). From the Fig.-1 showed a characteristic peak at 1600 that identify the presence of a carboxylic group decreased intensity by added ion Na.

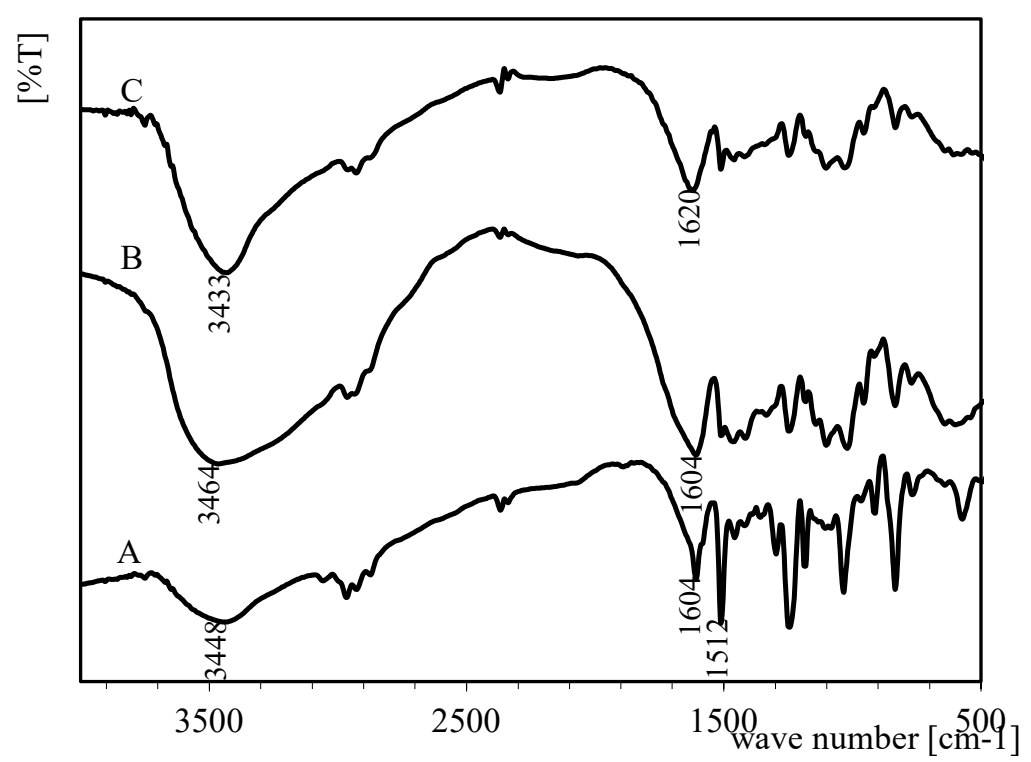

Fig-1: The FTIR spectra of: (A) CPB, (B) CPB-Na:1:1,(C) CPB-Na :3:1

\section{Scanning Electron Microscope (SEM) Characterization}

The difference structural morphology between Pec, Chi, CC, and CPB is supported by the difference in their SEM images. The SEM image of the surface of Pec, Chi, CC, and CPB, CPB-Na 1/1 and CPB-Na $1 / 3$ are shown in Fig.-2.

The SEM image of the surface of Pec, Chi, CC, and CPB are shown in Fig.-2. It is found that the surface of the Chi and CC shows a smooth, fibrous, and nonporous appearance, while a surface of Pec shows a rugged structure distributed in the particles. CPB shows a smoother surface than the others, and hence some holes and gaps are formed, which are scattered around the surface and interior. The porogen adsorbent of CPB-Na has a surface that is more porous than the Chi or Pec adsorbent. So the porous adsorbent of CPB$\mathrm{Na}$ will be easier binding $\mathrm{Pb}$ (II) metal ions than Chi and $\mathrm{Pec}$ without modification.

\section{Application as a Sorbent of $\mathrm{Pb}(\mathrm{II})$ \\ Effect of pH on Adsorption}

The adsorption properties of CPB-Na adsorbent to sorption of $\mathrm{Pb}$ (II) include the influence of $\mathrm{pH}$ reaction, kinetic and isotherm adsorption was reported. Adsorption was done in batch technique, at room temperature, and shaken at speed of $60 \mathrm{rpm}$. The effect of $\mathrm{pH}$ range between 2 to 6 , as shown in Fig.-3. Ion uptake of $\mathrm{Pb}$ (II) adsorbent is highly dependent on the $\mathrm{pH}$ of the solution because $\mathrm{pH}$ can affect the solubility of metal ions and ionized functional groups on the adsorbent.

\section{Adsorption Isotherms}

Adsorption isotherm describes the relationship between the concentration of solute in a solution and the amount of metal adsorbed on the adsorbent when the two phases at equilibrium. In this paper, Langmuir and Freundlich adsorption isotherm models were considered to describe the interaction between the solute and the adsorbent. 
RASĀYAN J. Chem.

Vol. 13 | No. 4 |2325-2331| October - December | 2020

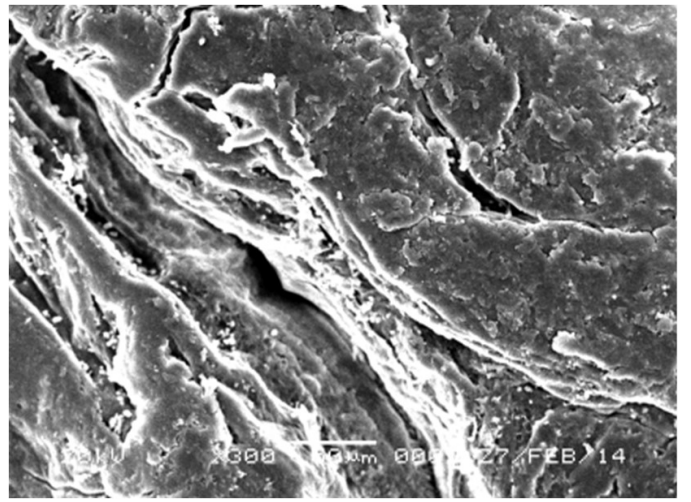

a

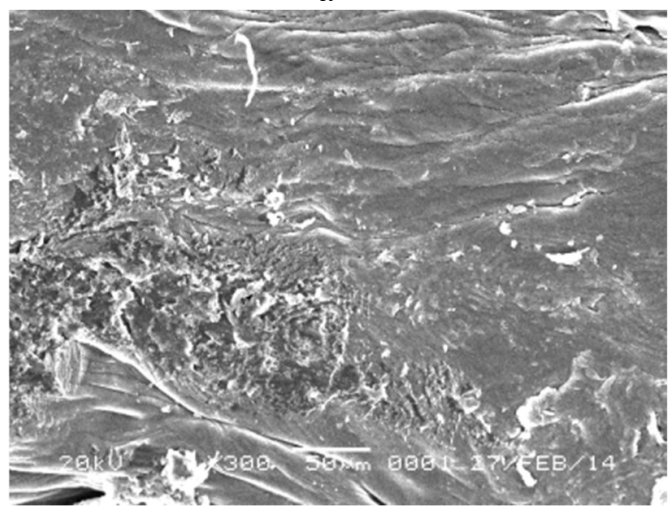

C

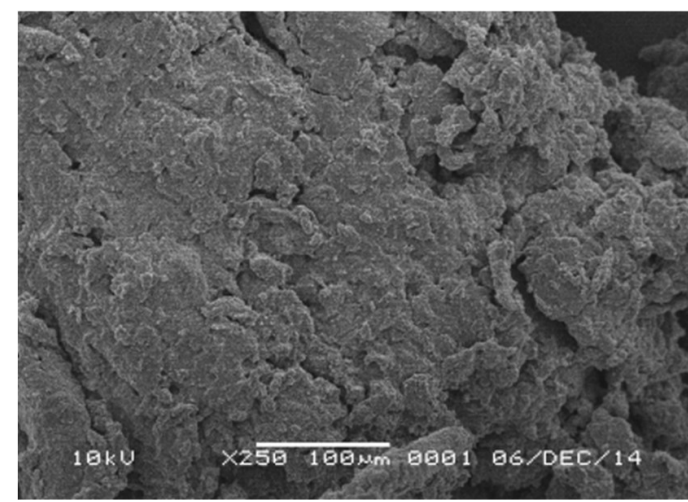

e

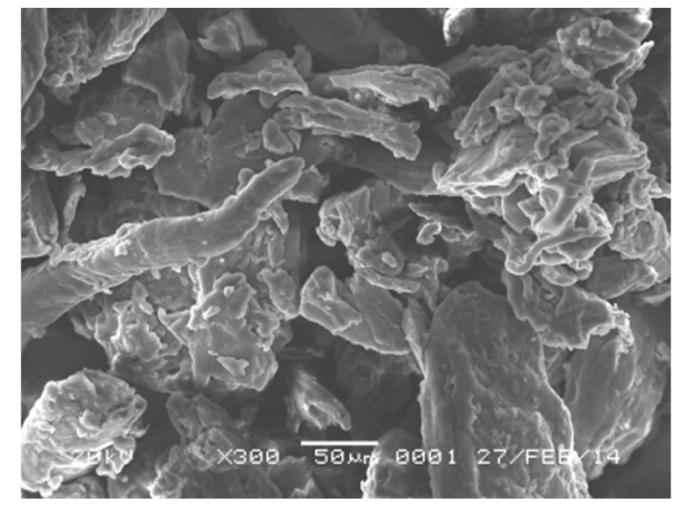

b

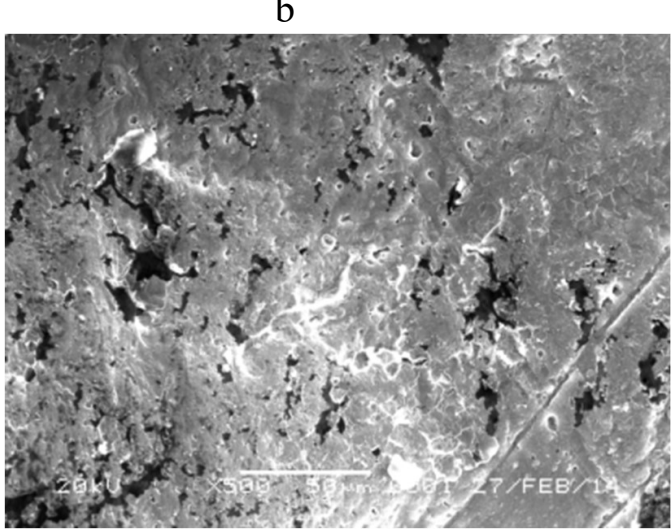

d

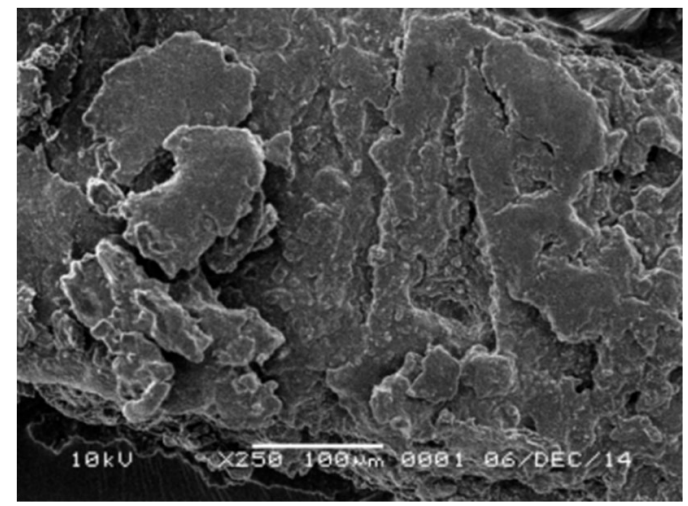

f

Fig-2.: SEM image of (a) Chi, (b) Pec, (c) CC, (d) CPB, (e) CPB-Na 1/1 and (f) CPB-Na 1/3

As shown in Table-1, The adsorption of $\mathrm{Pb}(\mathrm{II})$ ions from aqueous solution by CPB-Na $1 / 1$ and CPB-Na 1/3 shows a better fit to the Langmuir due to its higher $\mathrm{R}^{2}$ value $\left(\mathrm{R}^{2}=0.976\right.$ and 0.944$)$ respectively.

The Langmuir isotherm equation described adsorption process occurs on the adsorbent surface that has a finite number of sites with similar energy levels. The Langmuir model shows that the adsorbent surface has sites of identical energy and that each adsorbate molecule is assumed to be located on a single site. Hence, it predicts the formation of a monolayer of adsorbate on the adsorbent surface. ${ }^{19}$

Interaction between the metal ions of $\mathrm{Pb}(\mathrm{II})$ with the two of porogen adsorbent $\mathrm{CPB}-\mathrm{Na} 1 / 1$ and $1 / 3$ adsorbents was occurred by chemical adsorption, where the adsorption of $\mathrm{Pb}$ (II) metal ions occurs at the active sites of the adsorbent. Table- $1, \Delta \mathrm{G}^{\circ}$ value for adsorption of $\mathrm{Pb}$ (II) ion CPB-Na $1 / 1$ and CPB-Na $1 / 3$ are 23.83 and $22.08 \mathrm{~kJ}$ mol-1 respectively. Free energy for physisorption is generally lower than $20 \mathrm{~kJ}$ mol-1, the physisorption together with chemisorption is at a range of -20 to $-80 \mathrm{~kJ} \mathrm{mol-1}$ and chemisorption 
RASĀYAN J. Chem.

Vol. 13 | No. 4 |2325-2331| October - December | 2020

is at a range of -80 to $-400 \mathrm{~kJ}$ mol-1. This finding also suggests that the crosslinking process of BADGE between pectin and $\mathrm{CC}$ increases the strength of the interaction between $\mathrm{Pb}(\mathrm{II})$ and the adsorbent.

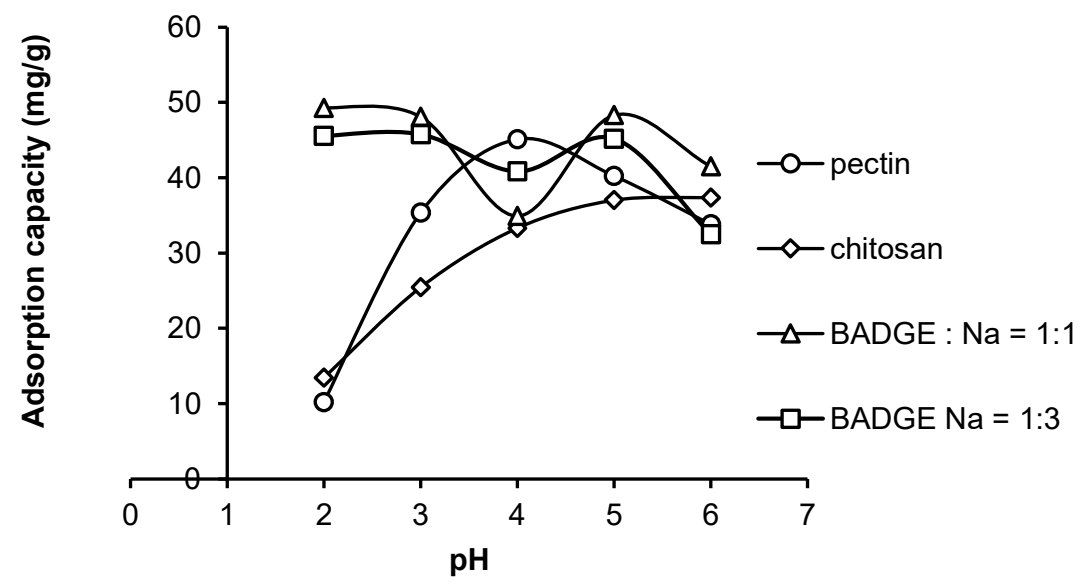

Fig-3: Effect of pH on Adsorption of Pb(II) Ion by Adsorbent Pec, Chi, CPB-Na 1:1 and CPB-Na 1:3

Table-1: Parameters of Langmuir and Freundlich Isotherm Adsorption of $\mathrm{Pb}(\mathrm{II})$

\begin{tabular}{l|c|c|c|c|c|c|c}
\hline \multirow{2}{*}{ Adsorbent } & & \multicolumn{5}{c}{ Parameter } \\
\cline { 2 - 8 } & & \multicolumn{3}{|c|}{ Langmuir } & \multicolumn{3}{c}{ Freundlich } \\
\cline { 2 - 8 } & $\begin{array}{c}\mathrm{b} \\
(\mathrm{mol} / \mathrm{g})\end{array}$ & $\begin{array}{c}\mathrm{K} \\
(\mathrm{L} / \mathrm{mmol})\end{array}$ & $\begin{array}{c}\Delta \mathrm{G} \\
(\mathrm{kJ} / \mathrm{mol})\end{array}$ & $\mathrm{R}^{2}$ & $\mathrm{n}$ & $\begin{array}{c}\mathrm{Kf} \\
(\mathrm{mg} / \mathrm{g})\end{array}$ & $\mathrm{R}^{2}$ \\
\hline $\mathrm{Chi}$ & $1.92 \times 10^{-3}$ & 2.53 & 19.54 & 0.616 & 3.38 & 0.691 & 0.976 \\
\hline $\mathrm{Pec}$ & $4.12 \times 10^{-3}$ & 0.19 & 16.60 & 0.150 & 1.04 & 0.936 & 0.866 \\
\hline $\mathrm{CPB}-\mathrm{Na} 1 / 1$ & $1.45 \times 10^{-3}$ & 14.13 & 23.83 & 0.976 & 5.35 & 1.229 & 0.365 \\
$\mathrm{CPB}-\mathrm{Na} 1 / 3$ & $1.61 \times 10^{-3}$ & 6.99 & 22.08 & 0.944 & 3.15 & 1.246 & 0.427 \\
\hline
\end{tabular}

Interaction between the metal ions of $\mathrm{Pb}(\mathrm{II})$ with $\mathrm{Chi}$ and $\mathrm{Pec}$ follows the Freundlich curve.The $\mathrm{Pec}$ and Chi adsorbent generate energy for 16,6 and 19,54 kJ/mol respectively. The adsorbent of Chi and Pec in the binding of $\mathrm{Pb}$ (II) metal ions occurs in a multilayer.

\section{Adsorption Kinetic}

Contact time effect on adsorption of $\mathrm{Pb}$ (II) ion by $\mathrm{Chi}, \mathrm{CC}$, Pec, porogen membrane CPB-Na $1 / 1$ and 1/3 were shown in Fig-4. Adsorption increased rapidly due to many actives sites of the adsorbent which still empty to bind $\mathrm{Pb}(\mathrm{II})$ ion quickly at the beginning. Exponentially by the time active sites on the adsorbent surface are gradually filled and the speed of adsorption decreases and eventually adsorption ability will be constant. At this time, active sites bound toward $\mathrm{Pb}(\mathrm{II})$ reach the maximum.

The optimal condition of Pec adsorbent to adsorb $50 \mathrm{ppm} \mathrm{Pb}$ (II) ion was 60 min of contact time and solution $\mathrm{pH} 4$, with an adsorption capacity of $39.20 \mathrm{mg} / \mathrm{g}$. The optimal condition of Chi and porogen adsorbent CPB-Na $1 / 1$ and $1 / 3$ were 60 min of contact time and solution $\mathrm{pH} 5$, with an adsorption capacity of 24.67 $\mathrm{mg} / \mathrm{g}, 45.48 \mathrm{mg} / \mathrm{g}$, and $45.97 \mathrm{mg} / \mathrm{g}$, respectively. This shows the modification of Pec and Chi by crosslinking processes and making it a porous adsorbent capable to increase their absorption capacity to $\mathrm{Pb}$ (II) metal ion.

The mechanism of sorption kinetics was determined by investigating two kinetics models, which then be used to test the experimental data. Adsorption kinetics was studied by modeling the data into a pseudo-firstorder kinetics equation (Lagergren) and pseudo-second-order kinetics equation. ${ }^{20}$ Pseudo-first-order (i) and pseudo-second-order (ii) kinetics equation are formulated as follows:

$$
\begin{aligned}
\ln (q e-q t) & =\ln (q e)-k l \mathrm{t} \\
\frac{\mathrm{t}}{\mathrm{q}_{\mathrm{t}}} & =\frac{1}{\mathrm{k}_{2} \mathrm{q}_{\mathrm{e}}^{2}}+\frac{1}{\mathrm{q}_{\mathrm{e}}} \mathrm{t}
\end{aligned}
$$


RASĀYAN J. Chem.

Vol. 13 | No. 4 |2325-2331| October - December | 2020

Where, $\mathrm{q}_{\mathrm{e}}$ and $\mathrm{q}_{\mathrm{t}}$ are the sorption capacity at equilibrium $\left(\mathrm{mmol} \mathrm{g}^{-1}\right)$ and at time $\mathrm{t}(\mathrm{min})$. Meanwhile, $\mathrm{k}_{1}$ is a pseudo-first-order rate constant $\left(\mathrm{min}^{-1}\right)$ and $\mathrm{k}_{2}$ is a rate pseudo-second-order constant $\left(\mathrm{g} \mathrm{mmol}^{-}\right.$ $\left.{ }^{1} \min ^{-1}\right)$.

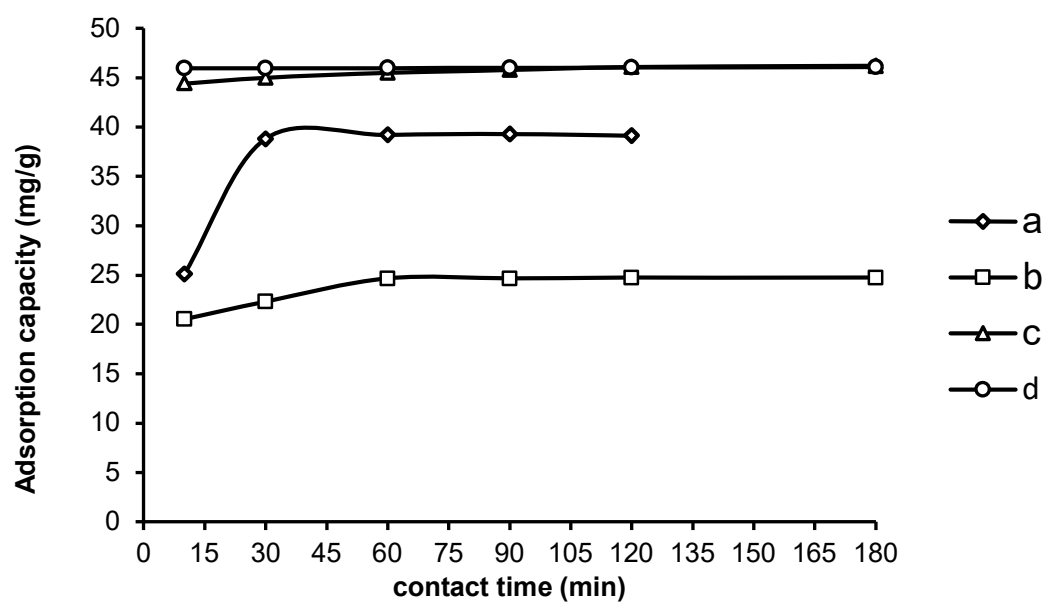

Fig.- 4.: Effect of Contact Time on the Adsorption Pb(II) by (a) Pec, (b) Chi, (c) CPB-Na 1/1 and d. CPB-Na 1/3

Table-2: The Kinetic Parameters of Adsorption of $\mathrm{Pb}(\mathrm{II})$ by the Adsorbents

\begin{tabular}{l|c|c|c|c|c|c}
\hline \multirow{2}{*}{ Adsorbent } & \multicolumn{5}{|c}{ Parameter } \\
\cline { 2 - 7 } & \multicolumn{3}{|c}{ Pseudo orde -1} & \multicolumn{3}{c}{ Pseudo orde 2 } \\
\cline { 2 - 7 } & $\begin{array}{c}\mathrm{q}_{\mathrm{e} 1} \times 10^{-6} \\
\left(\mathrm{~mol} / \mathrm{g}^{-1}\right)\end{array}$ & $\begin{array}{c}\mathrm{K}_{1}\left(\mathrm{x} 10^{-4}\right) \\
(1 / \mathrm{min})\end{array}$ & $\mathrm{R}^{2}$ & $\begin{array}{c}\mathrm{qe}_{2} \\
\left.\mathrm{~mol}_{\mathrm{g}} \mathrm{g}^{-1}\right)\end{array}$ & $\begin{array}{c}\mathrm{K}_{2} \\
(\mathrm{~g} / \mathrm{mmol} \mathrm{min})\end{array}$ & $\mathrm{R}^{2}$ \\
\hline $\mathrm{Pec}$ & 79.7 & 15 & 0.676 & 10.4 & 4.48 & 0,896 \\
$\mathrm{Chi}$ & 6.39 & 34 & 0.729 & 1.20 & 0.60 & 1 \\
\hline $\mathrm{CC}$ & 59.8 & 55 & 0.995 & 1.20 & 1.11 & 1 \\
\hline $\mathrm{CPB}-\mathrm{Na} 1 / 1$ & 10.3 & 145 & 0.982 & 2.24 & 12.3 & 1 \\
$\mathrm{CPB}-\mathrm{Na} 1 / 3$ & 2.76 & 56 & 0.898 & 2.24 & 15.1 & 1 \\
\hline
\end{tabular}

The results of the evaluation of kinetic constants of the adsorption are presented in Table-2. All of the adsorbent, Pec, Chi, CC, CPB-Na 1/1 and CPB-Na $1 / 1$ w e re well-suited with a pseudo-second- order kinetic model with an $\mathrm{R}^{2}$ value of $0.896,1.0,1.0,1.0,1.0$ and 1.0 respectively. Pseudo-secondorder kinetic was required when the adsorption processes are controlled by chemical bonding between adsorbent and adsorbate. ${ }^{21}$ Therefore, the adsorption mechanism of $\mathrm{Pb}$ (II) ion by all of the adsorbent, Pec, Chi, CC, CPB-Na 1/1 and CPB-Na 1/3. The reaction mechanism of CPB-Na toward $\mathrm{Pb}(\mathrm{II})$ would fit with the combination of chemisorption and physisorption, e.g. chelation and electrostatic adsorption.

\section{CONCLUSION}

The PCB membranes prepared by using $\mathrm{NaCl}$ particles as a porogen exhibited excellent sorption capacity. The adsorption equilibrium data of The CPB-Na membrane adsorbent were well fitted with Langmuir isotherm, which means the adsorption of metal ions $\mathrm{Pb}$ occurs at the active sites of the adsorbent. The adsorption process could be best described by the pseudo-second-order kinetic model show that The CPB$\mathrm{Na}$ membrane adsorbent was a good adsorbent of $\mathrm{Pb}(\mathrm{II})$ ion, which potentially provides a new way for the removal of heavy metal ions for the treatment of industrial wastewater.

\section{ACKNOWLEDGMENT}

The authors thank to the research funding support from the Indonesian Ministry of Research and also thank to Institute of Research and Community Services, Sebelas Maret University for the funding of Research through PNBP grant.

\section{REFERENCES}

1. E. Ardelean, R. Nicu, D.Asandei, and E. Bobu, European Journal of Science and Theology, 5, 4,(2009) 2. V.H. Waghmare and U.E. Chaudhari, Rasayan Journal of Chemistry, 7, 4 (2014). 
RASĀYAN J. Chem.

Vol. 13 | No. 4 |2325-2331| October - December | 2020

3. S. Sun and A.Wang, Journal of Hazardous Materials, 131, 1(2006), DOI:10.1016/ j.jhazmat.2005.09.012

4. K. Swayampakula, V.M. Boddu, S.K. Nadavala, and K. Abburi, Journal of Hazardous Materials, 170, 2(2009), DOI: 10.1016/j.jhazmat.2009.05.106

5. F. Fu, and Q. Wang, Journal of Environmental Management. 92, 3,(2011), DOI: 10.1016/j.jenvman.2010.11.011

6. H. Yan, J. Dai, Z. Yang, H. Yang, H. and R. Cheng, Chemical Engineering Journal, 174, 3(2011), DOI:10.1016/j.cej.2011.09.064

7. G.N. Kandile, and A.S. Nasr, Carbohydrate Polymers, 78, 4(2009), DOI: 10.1016/j.carbpol.2009.06.008

8. M.M. Fares, Y. R.Tahboub, S.T. Khatatbeh, and Y.M. Abdul Haija, Journal of Polymer Environmental, 19, (2011), DOI: 10.1007/s10924-011-0296-2

9. S.E. Bailey, T.J. Olin, R.M. Bricka, and D.D.Adrian, Water Research, 33, 11(1999), DOI: 10.1016/s0043-1354(98)00475-8

10. W. Stumm, and J.J. Morgan, Aquatic Chemistry: Chemical Equilibria and Rates in Natural Waters, John Wiley and Sons, INC, New York, (1996), DOI:10.5860/choice.33-6312

11. C.M.G.C. Renard, M.J. Crepeau and J.F. Thibault, Carbohydrate Research, 275, 1,(1995), DOI: 10.1016/0008-6215(95)00140-o

12. Y.N. Mata, M.L. Blázquez, F. Ballester, González and J.A. Mũnoz. Chemical Engineering Journal. 150(2-3),289(2009), DOI:10.1016/j.jenvman.2008.11.028

13. Schiewer, Silke and M. Iqbal, Journal of Hazardous Materials 177, 1(2010),DOI: 10.1016/j.jhazmat.2010.01.001

14. N.T. Kupchik, E.S. Kartel, O.V. Bogdanov, E.S. Bogdanov, and M.P Kupchik, Journal of Macromolecular Chemistry and Polymeric Materials, 79,(2006), DOI:10.1134/s1070427206030256

15. K. Oshita, M. Oshima, Y. Gao, K.H. Lee, and S. Motomizu, Journal Analytical Sciences, 18, (2002), DOI: 10.2116/analsci.18.1121

16. C. An-Chong. Y. Shu-Huei, and C. Guo-Syong, Journal of Membrane Science, 280,1(2006), DOI: 10.1016/j.memsci.2006.01.016

17. S.S. Rashidova, R.Y. Milusheva, L.N. Semenova, M.Y. Janova, N.L. Voropaeva, S. Vasilyeva, R. Faizieva, , and Ruban, Chromatograpia, 59, 11(2004), DOI:10.1365/s10337-004-0289-6

18. B. Hastuti, D. Siswanta, Mudasir, Triyono. Indonesian Journal of Chemistry, 15, 3(2015), DOI: $10.22146 /$ ijc. 21192

19. H.L. Vasconcelos, T.P,Camargo, N.S. Goncalves, A. Neves, M.C.M. Laranjeira, V.T. F'avere,. Reactive and Functional Polymers, 68, 2(2008), DOI:10.1016/j.reactfunctpolym.2007.10.024

20. Y.S. and Mc Kay, G. Process Biochemistry, 34, 5(1999), DOI:10.1016/s0032-9592(98)00112-5

21. M. Solener, S. Tunali, O.A Safa, and T. Gedikbey, Desalination, 223, 1(2008), DOI: 10.1016/j.desal.2007.01.221

[RJC-4091/2019] 